\title{
COLUBER NA JA.
}

Q

\section{CHARACTER GENERICUS。}

Scuta abdominalia.

Squama fubcaudales.

$$
\text { Lin. Syft. Nat. p. } 275 \text {; }
$$

\section{CHARACTER SPECIFICUS.}

\section{COLUBER FERRUGINEO-FLAVESCENS;} collo (plerumque) multum dilatato macula que fupra confpicillata albo nigroque varia notato.

Scuta abdominalia circiter 193.

Squamæ fubcaudales 60 .

Inter Europæorum commoda jure poteft reputari ferpentum venenoforum paucitas, qui in Indiæ et Africæ vaftis regionibus, nec non in Americæ late patentibus defertis denfo et horrendo dominantur agmine; nonnulli in exitium humani generis nimis, heu! lethaliter armati.

Omnes virulenti ferpentes dentibus tubulatis venenum per foramen e facculo maxillari in vulnus inflantibus, inftructi funt. Sunt tamen alii illis characteres quibus aliquatenus ab innoxiis ferpentibus diftingui 
tingui poffunt. Notavit Dominus $\mathrm{GrAr}_{\mathrm{Y}}$, in Actis Anglicis plerofque venenofos ferpentes caput latum, depreffum, fquamis minutis tectum habere; corporaque fquamis carinatis, feu linea elevata notatis obducta: at e contrario, innoxiis ferpentibus, qui morfu tantum fimplici lædunt, caput plerumque effe parvum, fquamis magnis et latis adopertum, corpufque fquamis lævibus, feu non carinatis. $\mathrm{Hi}$ autem characteres generales habendi funt, nec funt improvide et indubitanter recipiendi. Ita fe rem habere fpecies depicta exemplum eft clariffimum. Eft enim hic ferpens inter peftiferos fere dirifimus; et tamen externis illis fpecierum perniciofarum characteribus non diftinguitur; fed ut innocuo ferpenti caput eft illi plerumque parvum, fquamis magnis tectum; corpufque fquamis lævibus, feu non carinatis.

Tremendum hocce animal in India Orientali invenitur. Morfus ejus non minus quam Crotali funeftus eft. Ab Indiæ tamen incolis interdum capitur, et telis, feu dentibus tubulatis extractis (mirum dictu!) manfuefcit, et in varios modos, ad domini nutum, velut faltans, fe contorquet; et fæpe pro fpectaculo exhibetur. Nota, quam in collo habet fingularem, diverfis fpeciminibus plus minus vivida eft. Color etiam totius corporis in diverfis aliquatenus differt. In longitudinem aliquot pedum interdum crefcit hic ferpens.

Cum monftra bæc, regiones calidiores orbis incolentia, animo occurrunt, gratulari nobifmetipfis merito poffumus de noftra fecuritate; et lubentiffime anteponamus hyemis feptentrionalis incommoda, pigrofque 
campos et diu infructuofos, perenni climatis æftati, et floribus perpetuo ridentibus, quibus India utraque fuperbit : at ubi, proh dolor! viator incautus, media inter gaudia, fato fubitaneo corripitur. 
T H E

\section{SPECTACLE SNAKE,}

O R

\section{COBRA DE CA P E L L, O。}

.

GENERIC CHARACTER.

Tranfverfe Lamella under the abdomen. Broad alternate Scales under the tail.

SPECIFIC CHARACTER。

FERRUGGINOUS-YELLOW SNAKE, with the neck (generally) much dilated, and marked above by a fpectacle-fhaped fpot of black and white.

The abdominal plates are about 193 . The fubcaudal fcales 60 .

In Europe the noxious part of the ferpent tribe is happily confined to a very few poifonous fpecies; but the vaft regions of India and Africa, and the extenfive wilds of America, are infefted by a variety of thefe dreadful reptiles; fome of which are but too well provided with the fatal power of deftroying mankind by their bite. 


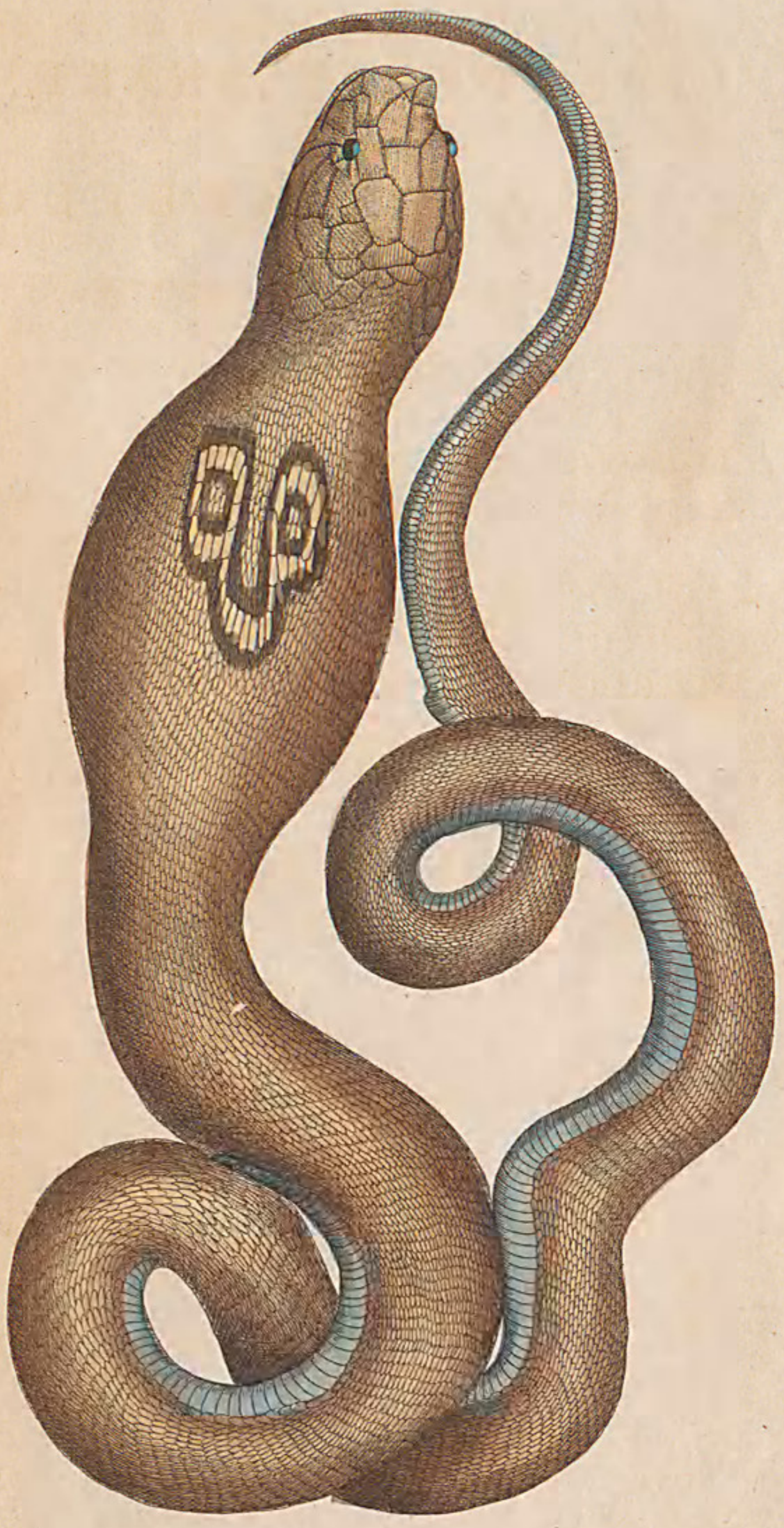



Such ferpents as are of a venomous nature, are furnifhed with tubular fangs, or teeth, through which their poifon, which is contained in refervoirs at the toots of the fangs, is injected into the wound. Befides the fangs, there are in general fome external characters which may in fome meafure ferve to diftinguifh the poifonous ferpents from the innoxious ones: thus it has been obferved by the ingenious Dr. GrAy, in the Philofophical Tranfactions, that the generality of poifonous ferpents have a broad, depreffed head, covered with fmall fcales; and that their bodies are commonly covered with carinated fcales, $i$. $e$. fcales which have a prominent line upon them. On the contrary; the innoxious ferpents, or fuch as can merely inflict a fimple wound, have generally a fmallifh head, covered with large broad fcales, and the body covered with fmooth fcales, or not carinated: but thefe are characters which admit of exceptions, and are merely to be regarded in a general view. The fpecies here figured is a ftriking inftance of this, and (as Dr. GRAY obferves) is in every refpect a complete exception to what has been faid refpecting the diftinction between venomous and innoxious ferpents; for though this is one of the mon terrible of the whole tribe, yet it is not diftinguifhed by thofe external marks of malignity which commonly characterize the poifonous fpecies: on the contrary, it agrees with the innoxious ferpents in having a fmallifh head, covered with very large fcales; while the body is covered with fmooth fcales. This formidable animal is a native of the Eaft-Indies. Its bite is not lefs deftructive than that of the RattleSnake, 
Snake. It is faid however to be fometimes caught by the Indians, and after having its fangs drawn, to be in fome degree tamed, fo as to be taught to throw itfelf into various fantaftic attitudes, as if dancing; and in this condition is often exhibited in India as a fhew. The very fingular mark on the neck is much more apparent in fome fpecimens than in others. The colour alfo of the whole body is deeper or lighter in different fpecimens. It grows to the length of fome feet.

Reflecting on thefe horrid natives of the hotter regions of the globe, we may congratulate ourfelves on our own happy ftate of fecurity, and may well be willing to prefer the rigours of a northern winter, with a temporary lofs of vegetation, to the continued warmth of climate, and ever-blooming verdure, which diftinguifh the beautiful regions of both the Indies; where alas! the incautious traveller may meet with fudden fate in the midft of the moft enchanting fcenes which nature can difplay. 


\section{$2 \mathrm{BHL}$ Biodiversity Heritage Library}

Shaw, George. 1791. "The Spectacle Snake or Cobra de Capello, Coluber naja [PI. 74]." The Naturalist's Miscellany 2(XXIV), https://doi.org/10.5962/p.310725.

View This Item Online: https://www.biodiversitylibrary.org/item/276232

DOI: https://doi.org/10.5962/p.310725

Permalink: https://www.biodiversitylibrary.org/partpdf/310725

\section{Holding Institution}

Museums Victoria

\section{Sponsored by}

Atlas of Living Australia

\section{Copyright \& Reuse}

Copyright Status: Public domain. The BHL considers that this work is no longer under copyright protection.

This document was created from content at the Biodiversity Heritage Library, the world's largest open access digital library for biodiversity literature and archives. Visit BHL at https://www.biodiversitylibrary.org. 